\title{
Reproductive biology of Gerres longirostris Lacepede, 1801 (Perciformes: Gerreidae) in the western Arabian Gulf
}

\author{
CHEHAB F. H. HOSNY AND ABDULRAHMAN M. AL-JABER* \\ Fish Resources Research Center, King Faisal University, Al-Hasa 31982, Saudi Arabia \\ "Department of Animal and Fish Production, College of Agricultural and Food Sciences King Faisal University \\ Al-Hasa 31982, Saudi Arabia \\ e-mail: chehab_hosny@yahoo.com
}

\begin{abstract}
Reproductive biology of the strongspine silverbiddy, Gerres longirostris Lacepede, 1801, was studied by examining 1910 individuals collected fortnightly between May 2012 and January 2014 from the western Arabian Gulf, off Saudi Arabia. The samples were identified as 470 males, 1370 females and 70 undetermined. Maximum length observed was 30 and $40 \mathrm{~cm}$ (total length TL) for males and females, respectively. Overall sex ratio of males to females was found to be 1:3.1. This sex ratio was significantly different from the normally expected 1:1 ratio $(\mathrm{p}<0.05)$. Males constituted more than $50 \%$ of individuals measuring less than $20 \mathrm{~cm}$ but this male-bias was not significant ( $>0.05$ ). Females were significantly greater than males in all size classes between 20 and $34 \mathrm{~cm}$ with high significant difference $(\mathrm{p}<0.05)$ from the expected 1:1 ratio between sexes. In length classes more than $34 \mathrm{~cm}, 100 \%$ of the fish were females. Size at first sexual maturity was estimated at 19.1 and $19.8 \mathrm{~cm}$ TL for females and males, respectively; all fish were mature at $20.7 \mathrm{~cm}$ TL. The spawning season coincided with late spring-early summer; gonadosomatic index (GSI) was highest (8.1-8.7 and 2.7-2.8 for females and males, respectively) in the peak season, May-June. GSI seems to peak in both sexes before 2-3 months of reaching the highest temperature. GSI and water temperature $(\mathrm{T})$ were best expressed by a second-degree polynomial equation for both sexes, indicating that water temperature $>30.28^{\circ} \mathrm{C}$ might not be optimal for reproduction of G. longirostris.
\end{abstract}

Keywords: Arabian Gulf, Gerres longirostris, Gonadosomatic index, Sex ratio, Size at first sexual maturity

\section{Introduction}

Strongspine silverbiddy, Gerres longirostris Lacepede, 1801, is a gerreid inhabiting the Indo-Pacific, ranging from the Red Sea and South Africa to the Marquesas Islands, north to the Ryukyu Islands, and south to Australia (Iwatsuki et al., 2001). Its presence was reported from Arabian Gulf (Carpenter et al., 1997) and the biology of this species has been studied from the western coast of the Arabian Gulf (Hosny et al., 2003) and in the southern Arabian Gulf off the United Arab Emirates (UAE) (Grandcourt et al., 2006). G. longirostris prefer sandy and silty grounds and are mostly found among sea grass beds and coral reefs (Sommer et al., 1996; Gell and Whittington, 2002). They attain a maximum length of $44.5 \mathrm{~cm}$ total length (TL) (Allen and Erdmann, 2012) and adults are often found in clear coastal waters down to $50 \mathrm{~m}$ depth; while juveniles occur in nearshore areas influenced by freshwater (Iwatsuki et al., 2001). Fry stages of about $10 \mathrm{~cm}$ in length enter the estuaries and stay until they reach maturity (Cyrus and Blaber, 1984).

Gonadal maturation in teleosts is quantified based on the colour, size and shape of their gonads and are macroscopically classified into different maturity stages.
Different workers have adopted various maturity schemes to classify gonads (Divakaran and Kuttyamma, 2014). The maturation status of fish varies among different habitats and this variation is likely to be due to the diverse environmental conditions. It has been reported that higher temperatures during pre-spawning season favoured rapid maturation of ovaries (Yamamoto and Shiah, 2013).

Studies on the reproductive biology of gerreids are relatively plenty, covering most of their geographical distribution. Jones and Sujansingani (1954); Jhingran (1957), Rao (1970), Patnaik (1971), Kurup and Samuel (1986; 1991), Sivashanthini and Ajmalkhan, (2004), Sivashanthini (2008), Renuka and Bhat (2011) have studied reproductive biology of gerreids in Indian waters. The same has been investigated by Austin (1971) and Etchevers (1978) in Venezuela; by Valdez-Zenil et al. (2014) in Mexico; Araujo and Santos (1999) in Brazil; Albaret and Desfossez (1988), Cyrus and Blaber (1984) and Whitfield (1998) in South Africa; Iqbal et al. (2007) and Kanak and Tachihara (2008) in Japan; Shutharshan and Sivashanthini (2011) in Sri Lanka; Sjafei and Syaputra (2009) in Indonesia and El-Agamy (1986) and Grandcourt et al. (2006) in the Arabian Gulf. 
Knowledge on the reproductive biology of a species is regarded as an important contributor in comprehending the dynamics of its population. To the best of our knowledge, there is no previous information on the reproductive biology of G. longirostris from the western Arabian Gulf. This paper reports for the first time, on the reproductive biology of this species in terms of sex ratio, size at first sexual maturity, monthly variations in gonadosomatic index and its relation with water temperature.

\section{Materials and methods}

Strongspine silverbiddy Gerres longirostris, were surveyed in the catch from commercial fishing operations performed off the coast of Saudi Arabia on the Arabian Gulf, from Salwa in the south up to Khafji in the North (Fig. 1). Biweekly samplings lasted from May 2012 until January 2014. The target was artisanal fishers on Dhows (large fishing boats or Sanbook) and speedboats (Tarrad) operating local fishing gears that are known to catch silverbiddies, i.e., wire traps (Gargoors), fixed gillnets (Manaseb), drifting gillnets (Ghozool) and hook and line (Hadag) (Hosny et al., 2003). From each fishing operation, weight of the total catch as well as the

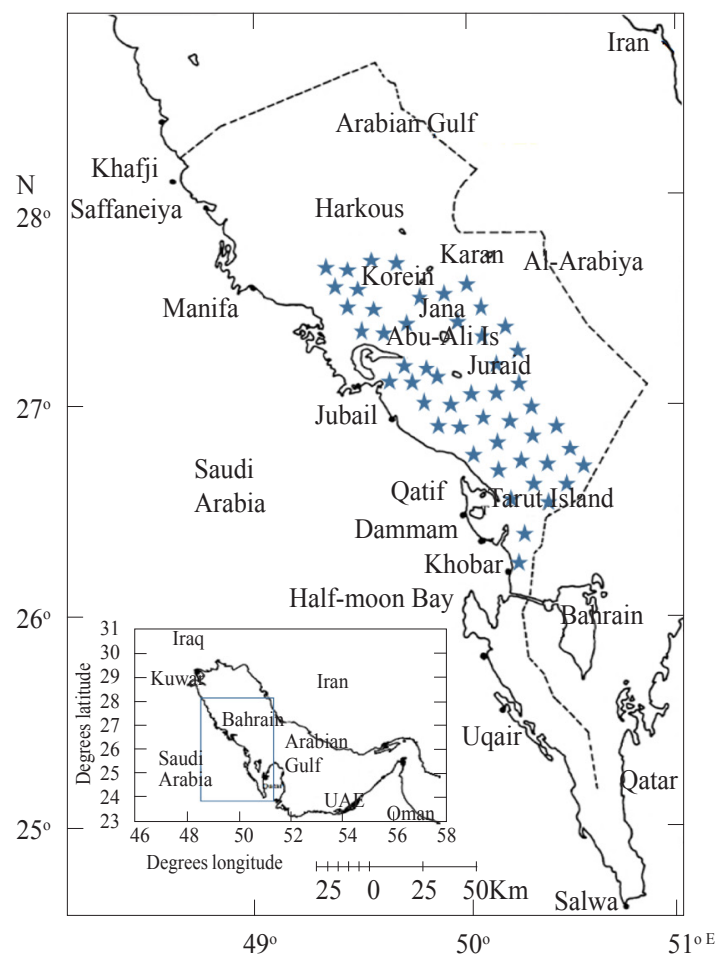

Fig. 1. Map showing major landmarks in the territorial waters of Saudi Arabia on the Arabian Gulf, marked with dashed line (insert shows Saudi territorial waters relative to the Arabian Gulf; blue rectangle shows enlarged area; blue stars mark locations where G. longirostris was present in the fishing gears during the study period) total weight of silverbiddies were recorded along with geographical location (using a GPS, Garmin gpsmap 276c) and bottom depth $(\mathrm{m})$ as well as water temperature $\left({ }^{\circ} \mathrm{C}\right)$. $G$. longirostris, were then separated from the catch according to fishing gear and samples were then collected at random as a percentage of the catch of silverbiddies, the monthly target sample size being 50 individuals.

In the laboratory, the sex of individuals was determined macroscopically after opening the abdominal cavity. A five-point maturity scale, which is the most commonly used and ideal for most tropical total spawners was adopted as follows: I - immature; II - maturing virgin and recovering spent; III - ripening; IV - ripe and V - spent (Qasim, 1957a, b; Qasim, 1973). Total length (TL) was measured to the nearest $\mathrm{mm}$ using digital slide calipers, total weight $\left(\mathrm{W}_{\mathrm{T}}\right)$ and gutted weight $\left(\mathrm{W}_{\mathrm{G}}\right)$ were recorded to the nearest gram $(\mathrm{g})$, while gonad weight $\left(\mathrm{G}_{\mathrm{w}}\right)$ was weighed to the nearest $0.001 \mathrm{~g}$ using a precision scale (Cole-Parmer ${ }^{\circledR}$ Symmetry ${ }^{\circledR}$ PR410).

Sex ratio was computed for the whole sample and then against $3 \mathrm{~cm}$ fish size class making 8 size classes (TL, cm). We conducted independent $\chi^{2}$ tests to determine whether sex ratios differ from the normal 1:1 ratio for the collected sample and for each size class. The probability level was set at 0.05 and Yates's correction factor (Sokal and Rohlf, 1995) was used.

The mean size at first sexual maturity $\left(\mathrm{L}_{\mathrm{m}}\right)$ was estimated for males and females by fitting the logistic function to the proportion of mature fish in a predefined $3 \mathrm{~cm}$ (TL) size classes. The mean size at first maturity was taken at a point where $50 \%$ of individuals were mature (Restrepo and Watson, 1991).

The reproductive cycle of the fish was determined from monthly changes in the gonadosomatic index (GSI) that was computed as: $\mathrm{GSI}=\mathrm{G}_{\mathrm{w}} / \mathrm{W}_{\mathrm{G}} * 100$, where, $\mathrm{G}_{\mathrm{w}}$ is the gonad weight and $\mathrm{W}_{\mathrm{G}}$ is the gutted weight in each sampled individual.

To establish the timing and frequency of spawning, GSI of males and females was plotted separately against the sampling period by month. The monthly mean water temperature in the study area was calculated from data measured in situ. Correlations between the monthly mean water temperature and GSI of both males and females were analysed by polynomial and linear correlations.

\section{Results and discussion}

There were 470 males $(24.61 \%), 1370$ females $(71.73 \%)$ and 70 undetermined $(3.66 \%)$ specimens in the samples collected $(n=1910)$. Males ranged in size between 30 and $16.9 \mathrm{~cm}$ TL and had an average size of $21.61 \pm 2.9 \mathrm{~cm}$. Females ranged in size between 
40 and $17.5 \mathrm{~cm}$ TL with an average size of $24.7 \pm 3.9 \mathrm{~cm}$. Specimens with undetermined sex ranged between 26.4 and $19.3 \mathrm{~cm}$ TL and had an average size of $22.3 \pm 2.1 \mathrm{~cm}$. The regional record for this species on the southern coasts of the Arabian Gulf, off Abu Dhabi is $33 \mathrm{~cm}$ fork length (FL) (Grandcourt et al., 2006) and off Oman is $37 \mathrm{~cm} \mathrm{TL}$ (Randall, 1995). All samples of G. longirostris were only from the catches of wire traps (Gargoors), fixed gillnets (Manaseb) and drifting gillnets (Ghozool).

According to the five-point maturity scale adopted in this study, female gonads and male testis were classified macroscopically and were found to fall under stages I to IV and spent individuals (stage V) were absent in the sampled catch. According to Cyrus and Blaber (1982), mature gerreids leave to spawn in open sea and spent individuals do not return to the shallow waters after spawning. Thus, the absence of spent individuals from our collection could be due to the poor coverage of deeper waters by artisanal fleets.

Sex ratio

The ratio of males to females represented in the sample collected for G. longirostris during the present study was found to be $1: 3.1$. This sex ratio differed significantly from the expected ratio of 1:1 $\left(\chi^{2}=439.240, \mathrm{p}<0.05\right.$; Table 1$)$. Such dominance of female over male individuals could be due to behavioural differences between the two sexes (Blaxter and Hunter, 1982). Previously published works on life histories of other gerreids showed sex ratio variations. In Gerres filamentosus, the sex ratio was found to be 1:11.4 in Cochin Estuary, India (Kurup and Samuel, 1991) and off Parangipetti coast of south-east India, sex ratio was 1:1 most of the year, but this ratio changed during the spawning season when males outnumbered females (Sivashanthini, 2008). The sex ratio of male and female Gerres kapas in Mayangan Coast, Subang, West Java, based on total fish and mature fish were unbalanced and varied between 1:3.1 and 1:9.3, respectively (Sjafei and
Syaputra, 2009). But in the Usumacinta River, Mexico, Eugerres mexicanus had a male to female ratio of 1:1.2 (Valdez-Zenil et al., 2014). This variability in the ratio between sexes may be caused by true differences in the composition of the local population or by sampling biases from fishing gears used. In the present study, gillnets tended to capture larger individuals, which were predominantly females, while the wire traps captured smaller size classes that were dominated by males. The overall sex ratio tended to be a function of the relative effort of the fishing gears used. Qasim (1966) suggested that the ponderance of one sex in a population was because of sexual differences in growth rate between sexes, the faster growth rate leads increasingly to less loss from predation and this might influence the sex ratio. In addition, Lowerre-Barbieri et al. (1996) suggested that the factors controlling the sex ratio within a fish population are gear selectivity, sexual segregation in growth, partial differences of mature fish and behavioral differences during spawning.

Furthermore, the sex ratio of $G$. longirostris among the 8 size classes assigned in the present study indicated that $>50 \%$ of the fish were males at TL of $<200 \mathrm{~mm}$ but this male-biased distribution was not significant (Table 1). However, there was a significant $(\mathrm{p}<0.05)$ female bias in the length classes $>340 \mathrm{~mm}$ where $100 \%$ were females. The sex ratio analysed by the $\chi^{2}$ test for each of the 8 size classes also showed that the number of females was significantly greater than that of males in all the size classes between 200-340 mm with significant difference $(p<0.05)$ from the expected 1:1 ratio between sexes. In accordance to this finding, there was a significant $(p<0.05)$ female bias in the overall male-to-female sex ratio of 1:2.2 in G. longirostris, in the southern Arabian Gulf, which was significant for all age categories (Grandcourt et al., 2006). Furthermore, a significant $(\mathrm{p}<0.05)$ female bias in the overall sex ratio of 1:1.9 for Acanthopagrus bifasciatus and 1:2.2 for Argyrops spinifer was observed in the southern Arabian Gulf (Grandcourt et al., 2004). However, the

Table 1. $\chi^{2}$ test of the sex ratio in 8 size classes of G. longirostris from the western Arabian Gulf off Saudi Arabia

\begin{tabular}{lllllll}
\hline \multirow{2}{*}{ Total length $(\mathrm{TL}, \mathrm{cm})$} & \multicolumn{3}{c}{ No. of fish } & \multirow{2}{*}{ Sex ratio $(\mathrm{M}: \mathrm{F})$} & \multirow{2}{*}{$\chi^{2}$} & $\mathrm{p}$ \\
\cline { 2 - 4 } & Male $(\mathrm{M})$ & Female $(\mathrm{F})$ & Total & & & \\
\hline $16-19$ & 70 & 60 & 130 & $1: 0.857$ & 0.623 & 0.43 \\
$20-22$ & 270 & 400 & 670 & $1: 1.481$ & $24.837^{*}$ & $6.24 \mathrm{E}-07$ \\
$23-25$ & 50 & 360 & 410 & $1: 7.200$ & $232.88^{*}$ & $1.40 \mathrm{E}-52$ \\
$26-28$ & 50 & 350 & 400 & $1: 7.000$ & $223.503^{*}$ & $1.56 \mathrm{E}-50$ \\
$29-31$ & 20 & 110 & 130 & $1: 5.500$ & $60.931^{*}$ & $5.91 \mathrm{E}-15$ \\
$32-34$ & 10 & 70 & 80 & $1: 7.000$ & $43.513^{*}$ & $4.21 \mathrm{E}-11$ \\
35 & 0 & 10 & 10 & $0: 1.000$ & $8.100^{*}$ & $4.43 \mathrm{E}-03$ \\
40 & 0 & 10 & 10 & $0: 1.000$ & $8.100^{*}$ & $4.43 \mathrm{E}-03$ \\
Total & 470 & 1370 & 1840 & $1: 3.089$ & $439.240^{*}$ & $1.58 \mathrm{E}-97$ \\
\hline
\end{tabular}

*Indicate significant difference 
sex ratios in size categories revealed that the female bias was present only at sizes below size at sexual maturation. The sex ratios in size categories above the mean size at first sexual maturity did not differ significantly from unity as revealed from $\chi^{2}$ goodness of fit tests (Grandcourt et al., 2004).

Size at first sexual maturity

Size at first sexual maturity was considered as the length at which $50 \%$ of the individuals were of maturity stage III and this was estimated at $19.1 \mathrm{~cm}$ for females and $19.8 \mathrm{~cm}$ for males. All males and females were mature at $20.7 \mathrm{~cm}$ total length. Similar observation of females attaining sexual maturity at a smaller size than males in gerreids have been made by Sivashanthini (2008) for G. filamentosus sampled off Parangipettai (south-east coast of India) and by Sjafei and Syputra (2009) for G. kapas in Mayangan Coast, West Java (Table 2).

On the other hand, some studies observed that gerreid males reached sexual maturity at smaller sizes than females. Rao (1970) reported this state for G. oyena in the Chilka Lake, Yeeting (1990) in Tarawa Lagoon, Kiribati and Lamtane et al. (2007) in Bagamoyo coast, Tanzania and Kanak and Tachihara (2008) in Okinawa Island, Japan. According to Patnaik (1971), 50\% of $G$. setifer males matured earlier than females in the Pulicat Lake (Table 2). In G. filamentosus, males have been reported to mature earlier than females in Cochin Estuary (Kurup and Samuel, 1991) and in Hong Kong (Sadovy and Cornish, 2000). This early maturity of males was also reported for G. equulus in western Kyushu, Japan (Iqbal et al., 2007) (Table 2). For G. longirostris, several records of size at first sexual maturity have been reported in different geographical localities but without reference to sex (Whitfield, 1998; Hosny et al., 2003; Hardman et al., 2008). In southern Arabian Gulf, along the coasts of UAE, males of $G$. longirostris were reported to mature earlier than females (Grandcourt et al., 2006) (Table 2).

In the present study, G. longirostris were found to mature at $20.7 \mathrm{~cm} \mathrm{TL}$ and hence from a managerial point of view it is suggested that capture of $G$. longirostris below $20.7 \mathrm{~cm}$ TL should be discouraged.

\section{Gonadosomatic index (GSI)}

The mean monthly GSI of female G. longirostris, whose lengths were $\geq \mathrm{L}_{\mathrm{m}}(19.1 \mathrm{~cm})$ were high at 5.3 in May 2012, which reached a peak of 7.45 in June 2012, before declining to 0.7 in July 2012 and then precipitously to 0.59 in December 2012 (Fig. 2). Subsequently, GSI remained at less than 2.2 until March 2013, after which they rose sharply from 3.2 in April 2013 to a well defined peak of 8.1-8.7 in May-June 2013, before sharply declining to 0.6 in August 2013 and then remained in an almost steady state till January 2014. Meanwhile, the trends exhibited by the mean monthly GSI of mature male $G$. longirostris, whose lengths were $\geq \mathrm{L}_{\mathrm{m}}(19.8 \mathrm{~cm})$ had the same pattern as described for females, with mean GSI exhibiting well defined peaks of 2.7-2.8 in May-June 2012 and 2.06-2.15 in May-June 2013 (Fig. 2). Thus, it seems that G. longirostris spawns during late spring and early summer. This single spawning period supports the argument that seasonal reproductive cycles are common among tropical fish (Robertson, 1990; Sadovy, 1996). However, several gerreid species were

Table 2. Size at first sexual maturity $\left(\mathrm{L}_{\mathrm{m}}\right)$ of gerreids from various studies

\begin{tabular}{|c|c|c|c|}
\hline \multirow{2}{*}{ Species } & \multicolumn{2}{|c|}{ Size at $1^{\text {st }}$ sexual maturity $\left(\mathrm{L}_{\mathrm{m}}\right)$} & \multirow{2}{*}{ Reference } \\
\hline & Males & Females & \\
\hline Eugerres mexicanus & $17.3 \mathrm{~cm}(\mathrm{TL})$ & $20.5 \mathrm{~cm}(\mathrm{TL})$ & Valdez-Zenil et al. (2014) \\
\hline Gerres equulus & n.a. & $14.1 \mathrm{~cm}(\mathrm{SL})$ & Iqbal et al. (2007) \\
\hline G. filamentosus & $14.38 \mathrm{~cm}(\mathrm{TL})$ & $13.66 \mathrm{~cm}(\mathrm{TL})$ & Sivashanthini (2008) \\
\hline G. filamentosus & $11.7 \mathrm{~cm}(\mathrm{SL})$ & $11.8 \mathrm{~cm}(\mathrm{SL})$ & Kurup and Samuel (1991) \\
\hline G. filamentosus & $12.0 \mathrm{~cm}(\mathrm{SL})$ & $19.0 \mathrm{~cm}(\mathrm{SL})$ & Sadovy and Cornish (2000) \\
\hline G. kapas & $11.5 \mathrm{~cm}$ & $10.5 \mathrm{~cm}$ & Sjafei and Syaputra (2009) \\
\hline G. longirostris & n.a. & 110 mm (SL) & Whitfield (1998) \\
\hline G. longirostris & $17.4 \mathrm{~cm}(\mathrm{TL})$ & & Hosny et al. (2003) \\
\hline G. longirostris & $23.8 \mathrm{~cm}(\mathrm{TL})$ & & Hardman et al. (2008) \\
\hline G. longirostris & $16.3 \mathrm{~cm}(\mathrm{FL})$ & $20.6 \mathrm{~cm}(\mathrm{FL})$ & Grandcourt et al. (2006) \\
\hline G. longirostris & $19.8 \mathrm{~cm}(\mathrm{TL})$ & $19.1 \mathrm{~cm}(\mathrm{TL})$ & Present study \\
\hline G. oyena & $12.8 \mathrm{~cm}$ & $13.9 \mathrm{~cm}$ & Lamtane et al. (2007) \\
\hline G. oyena & $16.4 \mathrm{~cm}$ & $18.9 \mathrm{~cm}$ & Rao (1970) \\
\hline G. oyena & $19.0 \mathrm{~cm}(\mathrm{FL})$ & $22.0 \mathrm{~cm}(\mathrm{FL})$ & Yeeting (1990) \\
\hline G. oyena & $9.2 \mathrm{~cm}(\mathrm{SL})$ & $10.4 \mathrm{~cm}(\mathrm{SL})$ & Kanak and Tachihara (2008) \\
\hline G. setifer & $7.1-8.0 \mathrm{~cm}$ & $8.1-9.0 \mathrm{~cm}$ & Patnaik (1971) \\
\hline
\end{tabular}

n.a. $=$ Data not available; $\mathrm{SL}=$ Standard length; $\mathrm{FL}=$ Fork length 


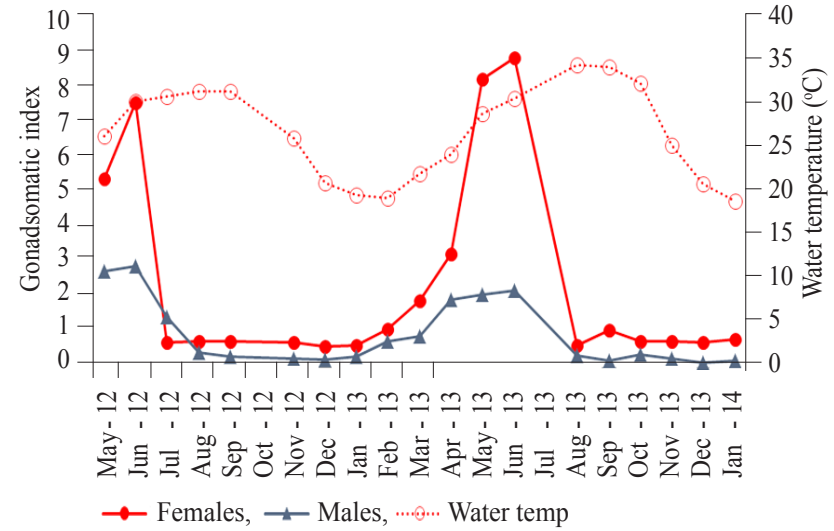

Fig. 2. Temporal variation of the mean gonadosomatic index (GSI) of G. longirostris from the Arabian Gulf off Saudi Arabia

observed to have an extended spawning season. In South Africa, Cyrus and Blaber (1984) stated that spawning occurs throughout the year for G. filamentosus, G. rappi and $G$. longirostris. The same has been reported for G. filamentosus in Cochin Estuary (Kurup and Samuel, 1991) and in Parangipettai (Sivashanthini, 2008). $G$. setifer has two defined spawning periods in Tanzania (Lamtane et al., 2007), while Eugerres mexicanus has a single defined spawning period in Usumacinta River (Valdez-Zenil et al., 2014). Nevertheless, it seems that within the same narrower geographical location, the spawning season of $G$. longirostris is a single defined one, as it was also reported from the southern Arabian Gulf that it breeds during a single defined period from April to August (Grandcourt et al., 2006).

The mean water temperature was lowest in January-February, ranging between 18.73 and $19.40^{\circ} \mathrm{C}$, began to increase in April $\left(24^{\circ} \mathrm{C}\right)$, reached the highest in August $\left(34^{\circ} \mathrm{C}\right)$ and then continuously decreased from November $\left(25^{\circ} \mathrm{C}\right)$ (Fig. 2). The GSI seems to peak in

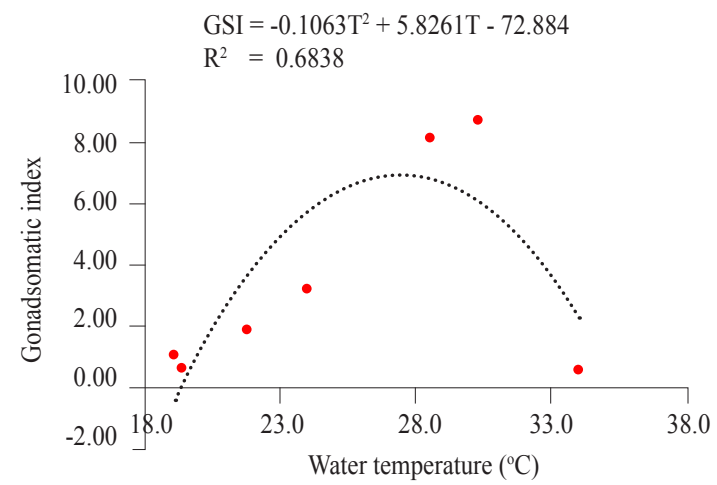

(a) both sexes by 2-3 months before the highest temperature is reached. The correlation between GSI and water temperature $(\mathrm{T})$ during the period of lowest temperature (January) through the peak recorded temperature (August) were found to be best expressed by a second-degree polynomial equation for both sexes, with an ascending limb from January $\left(19.40^{\circ} \mathrm{C}\right)$ to June $\left(30.28^{\circ} \mathrm{C}\right)$ and a descending limb from one July and August (Fig. 3). This indicates that water temperature above $30.28^{\circ} \mathrm{C}$ might not be optimal for reproduction in both females and males of $G$. longirostris. When the ascending limb between January and June, was considered separately, the linear correlation analysis showed positive significant $(p<0.05)$ correlation coefficients of 0.9695 and 0.8491 for females and males, respectively. The linear equations expressing this relation were found to be:

$\mathrm{GSI}=0.7531 \mathrm{~T}-14.026$ in females,

$\mathrm{GSI}=0.1556 \mathrm{~T}-2.3682$ in males

As a management tool, a seasonal closure of the silverbiddies' fishery is thus a requirement during the period from 1 March to 31 July every year. A similar regulation is being enforced in the southern Arabian Gulf, where it is banned during 1 April to 21 July (Grandcourt et al., 2006). The suggested regulation should be backed up by a ban of gargoors used for catching silver biddies, as gargoors have been observed to catch predominantly small sized individuals.

The G. longirostris population in the western Arabian Gulf seems to be female biased throughout most of the size range of the adult while, part of the population matures at $20.7 \mathrm{~cm}$ total length. As per GSI, G. longirostris spawns in a single season annually and its reproductive activity might peak in late spring and early summer. The reproductive activity of $G$. longirostris drastically decreases when the water temperature exceeds $30.28^{\circ} \mathrm{C}$.

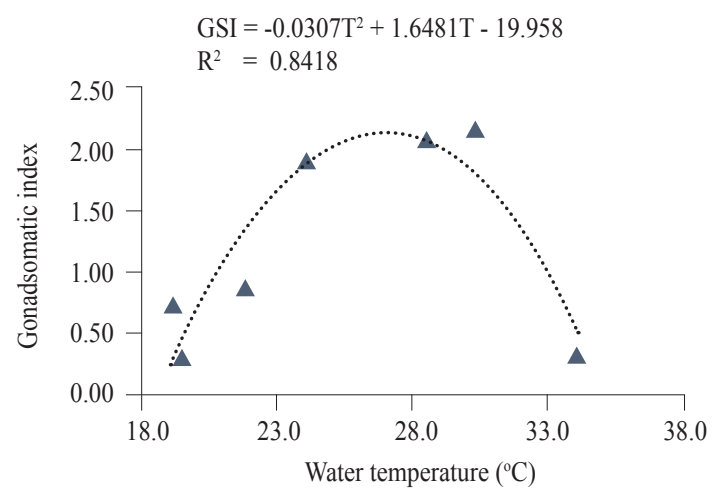

(b)

Fig. 3. GSI plotted against water temperature for (a) females and (b) males of G. longirostris during winter and early summer (January-June 2013) 


\section{Acknowledgements}

The authors express their appreciation to the Deanship of Scientific Research, King Faisal University for the financial support for this study through grant No. $130113 / 238$.

\section{References}

Albaret, J. J. and Desfossez, P. 1988. Biology and ecology of Gerreidae (Pisces, Teleostei) in the Ebrie Lagoon (Ivory Coast). Rev. Hydrobiol. Trop., 21: 71-88.

Allen, G. R. and Erdmann, M. V. 2012. Reef fishes of the East Indies, Tropical Reef Research, vol. I-III. Universitiy of Hawaii Press, Perth, Australia.

Araujo, F. G. and Santos, A. C. de-A. 1999. Distribution and recruitment of mojarras (Perciformes: Gerreidae) in the continental margin of Sepetiba Bay, Brazil. Bull. Mar. Sci., 65(2): 431-439.

Austin, H. M. 1971. Some aspects of the biology of the rhomboid mojarra Diapterus rhombeus in Puerto Rico. Bull. Mar. Sci., 21: 886-903.

Blaxter, J. H. S. and Hunter, J. R. 1982. The biology of clupeoid fishes. Adv. Mar. Biol., 20: 1-223.

Carpenter, K. E., Krupp, F., Jones, D. A. and Zajonz, U. 1997. Living marine resources of Kuwait, eastern Saudi Arabia, Bahrain, Qatar and the United Arab Emirates. FAO species identification field guide for fishery purposes. $293 \mathrm{pp}+17$ col. plates, FAO, Rome.

Cyrus, D. P. and Blaber, S. J. M. 1982. Species identification, distribution and abundance of Gerreidae (Teleostei) Bleeker 1859, in the estuaries of Natal. S. Afr. J. Zool., 17: $105-116$.

Cyrus, D. P. and Blaber, S. J. M. 1984. The reproductive biology of Gerres (Teleostei) Bleeker 1859, in Natal estuaries. J. Fish Biol., 24: 491-504.

Divakaran, N. and Kuttyamma, V. J. 2014. Reproductive biology of common silverbiddy, Gerres filamentosus (Cuvier). $A d v$. Appl. Sci. Res., 5(4): 144-152.

El-Agamy, A. E. 1986. The fecundity of Gerres oyena Forskal 1775, (Fam. Gerreidae) in the Qatari waters of the Arabian Gulf. Qatar Univ. Sci. Bull., 6: 371-388.

Etchevers, S. L. 1978. Contribution to the biology of Diapterus rhombeus (Cuvier) (Pisces-Gerreidae), South of Margarita Island, Venezuela. Bull. Mar. Sci., 28: 385-389.

Gell, F. R. and Whittington, M. W. 2002. Diversity of fishes in seagrass beds in the Quirimba Archipelago, northern Mozambique. Mar. Freshwat. Res., 53: 115-121.

Grandcourt, E. M., Al Abdessalaam, T. Z., Francis, F. and Al Shamsi, A. T. 2004. Biology and stock assessment of the Sparids, Acanthopagrus bifasciatus and Argyrops spinifer (Forsskal, 1775), in the Southern Arabian Gulf. Fish. Res., 69(1): 7-20.
Grandcourt, E. M., Al Abdessalaam, T. Z., Francis, F. and Al Shamsi, A. T. 2006. Fisheries biology of a short-lived tropical species: Gerres longirostris (Lacepede, 1801) in the Arabian Gulf. ICES J. Mar. Sci., 63: 452-459.

Hardman, E. R., Blais, F. E. I., Desire, M. S., Raffin, J. S. J., Perrine, S. and Meunier, S. 2008. Annual report on the status of the artisanal seine net fishery of rodrigues 2007. Shoals Rodrigues, Pointe Monier, Rodrigues, 53 pp.

Hosny, C. F. H., Al-Suwailem, A. M. and Hassan, A. K. 2003. Studies of the ecological factors affecting fish stocks in the Arabian Gulf. KACST Project No. AR-16-110, Final Report, $461 \mathrm{pp}$.

Iqbal, K. M., Ohtomi, J. and Suzuki, H. 2007. Reproductive biology of the Japanese silverbiddy, Gerres equulus, in western Kyushu, Japan. Fish. Res., 83: 145-150.

Iwatsuki, Y., Kimura, S. and Yoshino, T. 2001. Redescription of Gerres longirostris (Lacepede, 1801) and Gerres oblongus Cuvier in Cuvier and Valenciennes, 1830, included in the Gerres longirostris complex (Perciformes: Gerreidae). Copeia, 4: 954-965.

Jhingran, V. G. 1957. Age determination of the Indian major carp Cirrhina mrigala (Ham.) by Means of scales. Nature, 179: 468-469.

Jones, S. and Sujansingani, K. H. 1954. Fish and fisheries of the Chilka Lake with statistics of fish catches for the years 1948-50. Indian J. Fish., 1(1-2): 256-344.

Kanak, M. K. and Tachihara, K. 2008. Reproductive biology of common silverbiddy Gerres oyena in Okinawa Island of southern Japan. Fish. Sci., 74: 265-275.

Kurup, B. M. and Samuel, C. T. 1986. Observations on the food and feeding habits of the whipfin majorra Gerres filamentosus Cuvier (Perciformes: Gerridae) of the Vembanad Lake. Bull. Dept. Mar. Sci. Univ. Cochin, XIV: 89-98.

Kurup, B. M. and Samuel, C. T. 1991. Spawning biology of Gerres filamentosus Cuvier in the Cochin Estuary. Fish. Tech., 28: 19-24.

Lamtane, H. A., Pratap, H. B. and Ndaro, S. M. G. 2007. Reproductive biology of Gerres oyena (Pisces: Gerreidae) along the Bagamoyo Coast, Tanzania. Western Indian Ocean. J. Mar. Sci., 6(1): 29-35.

Lowerre-Barbierei, S. K., Chittenden, M. E. Jr. and Barbieri, L. R. 1996. The multiple spawning pattern of weakfish in the Chesapeake Bay and Middle Atlantic Bight. J. Fish Biol., 48: 1139-1163.

Patnaik, S. 1971. Observations on the fishery and biology of Chilka Jagili, Gerres setifer (Hamilton). J. Inland Fish. Soc. India, 3: 25-43.

Qasim, S. Z. 1957a. The biology of Blennius pholis L. (Teleostei). Proc. Zool. Soc. Lond., 128: 161-208.

Qasim, S. Z. 1957b. The biology of Centronotus gunnellus (L.) (Teleostei). J. Anim. Ecol., 26: 389-401. 
Qasim, S. Z. 1966. Sex ratio in the fish population as a function of sexual difference in growth rate. Curr. Sci., 35: 140-142.

Qasim, S. Z. 1973. An appraisal of the studies on maturation and spawning in some marine teleosts from the Indian waters. Indian J. Fish., 20(1): 166-181.

Randall, J. E. 1995. Coastal fishes of Oman. University of Hawaii Press, Honolulu, Hawaii. 439 pp.

Rao, A. V. P. 1970. Observations on some aspects of the biology of Gerres oyena (Forskal) with notes on the fishery of silverbiddies of Pulicat Lake. J. Inland Fish. Soc. India, 2(1): $85-100$.

Renuka, G. and Bhat, U. G. 2011. Fecundity of whipfin silver biddy Gerres filamentosus (Cuvier) from Sharavati Estuary, central west coast of India. Rec. Res. Sci. Tech., 3(4): 71-74.

Restrepo, V. R. and Watson, R. A. 1991. An approach to modeling crustacean egg-bearing fractions as a function of size and season. Can. J. Fish. Aquat. Sci., 48: 1431-1436.

Robertson, D. R. 1990. Differences in the seasonalities of spawning and recruitment of some small neotropical reef fishes. J. Exp. Mar. Biol. Ecol., 144: 49-62.

Sadovy, Y. J. 1996. Reproduction of reef fishery species. In: Polunin, N. V. C. and Roberts, C. M. (Eds.), Reef fisheries. Chapman and Hall, London, p. 15-59.

Sadovy, Y. and Cornish, A. S. 2000. Reef fishes of Hong Kong. Hong Kong University Press, 321 pp.

Shutharshan, S. and Sivashanthini, K. 2011. Growth characteristics of slender silverbiddies Gerres oblongus (Pisces: Perciformes) from the Jaffna Lagoon, Sri Lanka. J. Fish. Aquat. Sci., 6: 592-603.

Sivashanthini, K. 2008. Reproductive biology of the whipfin silverbiddy Gerres filamentosus Cuvier, 1829 from the
Parangipettai waters (SE coast of India). Asian Fish. Sci., 21: $127-145$

Sivashanthini, K. and Ajmalkhan, S. 2004. Population dynamics of Gerres setifer (Hamilton, 1822) in the Parangipettai waters, south-east coast of India. Indian J. Mar. Sci., 33: $352-357$

Sjafei, D. S. and Syaputra, D. D. 2009. Reproductive aspect of silverbiddy (Gerres kapas Blkr, 1851, Fam. Gerreidae) in Mayangan Coast, West Java. Jurnal Iktiologi Indonesia, 9(1): 75-84.

Sokal, R. R. and Rohlf, F. J. 1995. Biometry: The principles and practice of statistics in biological research., $3^{\text {rd }}$ edn. W. H. Freeman, New York, 880 pp.

Sommer, C., Schneider, W. and Poutiers, J. M. 1996. The living marine resources of Somalia. FAO species identification field guide for fishery purposes, FAO, Rome, $376 \mathrm{pp}$.

Valdez-Zenil, J., Rodiles-Hernandez, R., Gonzalez-Acosta, A. F., Mendoza-Carranza, M. and Barba Macias, E. 2014. Length-weight and length-length relationships, gonadosomatic indices and size at first maturity of Eugerres mexicanus (Steindachner, 1863) (Percoidei: Gerreidae) from the Usumacinta River, Mexico. J. Appl. Ichthyol., 30: $218-220$.

Whitfield, A. K. 1998. Biology and ecology of fishes in southern African estuaries. J. L. B. Smith Institute of Ichthyology, South Africa, 223 pp.

Yamamoto, Y. and Shiah, F. K. 2013. Spatial variation in reproductive measures of female bluegill Lepomis macrochirus Rafinesque in a small lake with diverse thermal conditions. Zool. Stud., 52: 19.

Yeeting, B. M. 1990. Notes on the silverbiddy Gerres oyena in Tarawa Lagoon, Kiribati. Fishbyte, 8(3): 8-10. 